\title{
YENİ BULGULAR IŞIĞINDA 1962 KÜBA KRİZİ VE TÜRKIYE
}

\author{
Dr. Ayşegül SEVER*
}

Otuzbeş yıl once, ABD'nin Küba topraklarına Sovyculer Birliği'nce orta menzilli nükleer başlık taşıyan füzzeler yerleşuriildiğini saptamasıyla 16 Ekim 1962'de patlak veren Küba krizi, taraflanı ilk kez nükleer savaşın eşiğine getirmesi açısından en önemli soguk savaş krizlerinden biri oldu ve soğuk savaş döneminin pek çok dramatik olayı gibi bütün yönleriyle ancak son yıllarda aydınlanıyor. Son on yılda yeni arşiv belgelerinin açılması ve 1987'den başlayarak ard arda toplanan bir dizi uluslararası konferansta, krize ilk elden tanıklık eden SSCB, ABD ve Kübalı birçok siyasetçi ve diplomatın yaptıklanı önemli açıklamalarla Küba bunalımı birçok yönüyle yeniden irdelendi. ${ }^{1}$ Bunalımla ilgili bu yeni degerlendirmeler Sovyet lideri Nikita Khruschev'in ABD Başkanı John F. Kennedy'den Küba'daki füzelere karşılık tzmir-Ciğli'de konuşlandırılan ortà menzilli Jüpiter füzelerinin (IRBM) sökülmesini isteyen 27 Ekim 1962 tarihli mesajıyla taraf olan Türkiye için de yeni çıarımlar içeriyor. Bu makalede son zamanlardaki yeni değerlendirmeler doğrultusunda krizin genel gidişatı değil; ancak Jüpiter füzelerinin krizin gelişimi ve çözümündeki yeri önce uluslararası açıdan genel bir çerçevede daha sonra da ulusal düzeyde Türkiye açısından öznel bir biçimde iki düzeyli bir analizc konu olacaktur.

\footnotetext{
* Marmara Universitesi, IIBF, Siyaset Bilimi ve Uluslararası Llişkiler Bölümü

1987-92 yılları arasında Harvard ve Brown üniversitelerinin sponsurluğunda Küba, Sovyetler Birliği ve ABD'den krize ilk elden tanıklık etmiş ülke temsilcilerinin ve akademisyenlerin katılımıyla Küba krizini bütün yönleriyle aydınlatmak üzere bir dizi uluslararası konferans toplandı. Bu uluslararası konferansların beşinci ve sonuncusu Havana'da Fidel Castro'nun da katılımıyla gerçekleşti ve krizle ilgili bilinmeyenlerin günısı̆ğına çıkması bakımındian tarihi bir nitelik kazandı. Bu konferanslar, arşivlerden ozellikle Amerikan Ulusal ve Başkanlık arşivlerinden derlenen bilgilerin tamamlanmasında çok önemli rol oynadılar. Bu arada eski Sovyet arşivlerinden her geçen gün artarak elde edilen veriler krizi daha da aydınlatacak gibi görünmektedir.
} 


\section{Uluslararası Politika Açısından Türkiye'de Konuşlandırılan Jüpiter Füzelerinin Küba Krizindeki Yeri}

Eisenhower yönetimi, 1957 yılında Sovyetlerin ilk yapma uydu Sputnik'i uzaya furlatmak ve kıtalararası füzelere sahip olmak suretiyle (ICBM) kaydettikleri teknolojik ilerlemeleri dengelemek üzere Avrupa'ya orta menzilli füzeler - Jüpiter ve Thor konuşlandirmaya karar verdi. ABD'nin bu kararına olumlu yanit sadece 3 NATO ülkesinden - Ingiltere, Italya ve Türkiye -'den geldi. Ingiltere'ye 60 Thor füzesi konuşlandırilırken, Italya ve Türkiye'ye toplam 45 adet Jüpiter füzesi gönderilecekti. Türkiye'ye 15 adet Jüpiter füzesi konuşlandırılmasına ilişkin Türk-ABD antlaşması 28 Ekim 1959'da imzalandı. Küba krizinde de Sovyetlere diğerlerine göre coğrafi yakınlığından olsa gerek Türkiye'ye yerleştirilen bu Jüpiterler daha çok gündeme gelecekti.

Ekim 1959 ABD-Türkiye andlaşması uyannca tzmir-Çiğli'de konuşlandırılan orta menzilli 15 Jüpiter füzesi, gerek Küba bunalımının patlak vermesinde gerek çŏzümlenmesinde önemli bir etken olarak gündeme geldi. Günümüz değerlendirmelerinde, Sovyetlerin Küba'ya füze konuşlandırma kararının ana nedeni değilse de ónemli nedenlerinden biri olarak Türkiye'ye yerleştirilen bu füzeler gösterilmektedir. Özellikle Sovyet kaynaklan Küba'ya füze konuşlandırma kararının arkasında ABD'nin Kübayı işgalini ơnleme kaygısını ve SSCB'nin nükleer vuruş kapasitesini artırma amacını iki onde gelen sebep olarak sıralarken, Sovyetleri yakından çevrelemeleri itibariyle Jüpiter füzelerini de, konuşlandırma kararında üçüncü bir etmen olarak, ózellikle psikolojik açıdan, hesaba katuyorlar. ${ }^{2}$

Bu bağlamda da Jüpiterlerin söz konusu krizde, kapasitelerinin ötesinde, işlevselliklerini aşan bir rol oynadıklan görülüyor; zira Jüpiterlerin savunma silahı olarak ciddi zafiyetleri olduğu bilinmektedir. Füzclerin yüzeyleri çok ince ve en ufak darbede delinmeye müsait, ateşlemeleri saatler alıyor, isabet oranlan düşük ve sadece ilk vuruş için uygun olduklarından da saldırıyı önlemekten ziyade kışkırtıcı, adeta saldınya davetiye çıkaran bir özellik taşıyorlardı. ${ }^{3}$ Bu özellikler gözönüne alındığında ABD'nin Jüpiterleri yerleştirme karan almasında bu füzelerin askeri yararlıluklarından ziyade başka etmenlerin rol oynadığı ortaya çıkıyor. Eisenhower yönctimi 1957 yılında Sovyetlerin Sputnik ve kıtalararası füzelerde (ICRB) elde ettiği üstünlüğü zaman kaybetmeden dengelemek zorunluluğunu hissediyordu. Aksi takdirde Amerikan ve dünya kamuoyu Sovyetlerin bu gelişkin vurma kapasiteleri karşısında Washinton'u acz. içinde görecek, ABD'nin prestiji ve güvenilirliği zedelenecekti. Bu durumda Eisenhower yönetimi uzun menzilli füzelere sahip oluncaya kadar Sovyctlerle arasındaki füzc boşluğunu Avrupa'ya yerleşireceği orta menzilli füzclerle gidermeyi yeğledi. Görülüyor ki bu kararıla yönetim iç ve diş kamuoyunda prestij kaybetme kaygısıyla hareket ederek, füzelerin askeri bakımdan

${ }^{2}$ Laurence Chang and Peter Kombluh (Ed.), The Cuban Missile Crisis, 1962 - A National Archives Documents Reader (New York: The New Press, 1992), s.351; Bruce J.Allyn, James G.Blight and David A.Welch, 'Essence of Revision', International Security, Vol.14, Winter 1989-90, ss.138-139; Raymond L. Garthoff, Reflections on the Cuban Missile Crisis (Washington, D.C. : The Brooking Institution, 1989), s.24. '

${ }^{3}$ Barton Bernstein, 'The Cuban Missile Crisis: Trading The Jupiters in Turkey?', Political Science Quarterly, Vol.95, 1980., s.99. 
zafiyetlerini gözardı ediyor ve dolayısıyla da 'siyasi ve psikolojik' bir karar almıs oluyordu. ${ }^{4}$

Alınan bu karar doğrultusunda ABD, Başkan Eisenhower'n da katıldığı 16-19 Aralık 1957'deki tarihi NATO Paris zirvesinde orta menzilli füzeleri Avrupa'ya konuşlandırma kararını müttefikleri nezdinde gündeme getirdi. Türkiye hariç katılımcıların bu öneriye tepkisi pek de yüreklendirici olmadı. ${ }^{5}$ IRBM'ler konuşlandırılacakları ülkeyi hedef haline getireceğinden ve de bu füzeleri ateşlemede kimin yetkili olacağı sorusu kafalan kurcaladı̆̆ından ABD ơnerisine müttefiklerin genel tepkisi nötr ya da olumsuz oldu. Bu genel tepkide Sovyet tutumunun da etkisi olduğu söylenebilir. Nitekim bu konuşlandırma önerisinin hemen öncesinde SSCB bir zirve onerisinde bulunarak mütteffikler nezdinde konuşlandırmanın tansiyonu arurabileceği imajını yaratmış, bununla da yetinmeyip sőz konusu füzeleri topraklanına kabul edecek ülkclere yönelik tehditler savurmayı da ihmal etmemişti. ${ }^{6}$

Müttefiklerinin mesafeli tepkisine karşın IRBM'lerin Avrupa'da bir an once konuşlandırılması, Amerikanın vuruş kapasitesini artıracak olan uzun menzilli füzelerin ancak Haziran 1959 'da, Akdenizde konuşlandınlacak olan Polaris füzesi taşıyacak denizaltılarının da 1960 sonlarında operasyonel hale gelebileceği düşünüldüğünde ABD için ayn bir önem taşıyordu. ${ }^{7}$ Bu nedenle Eisenhower yönetimi önce Fransa sonra da ltalya ile IRBM'ler konusunda görüşmelerc başladı. Müttefikler arasında konuşlandırmaya en istekli görünen ülke Türkiye olsa da, çeşitli nedenler dolayısıyla Türkiye olası evsahipleri listesinde liste başı olamayacaktı. Herşeyden önce gerek NATO Müttefik Kuvvetleri Başkomutanı Lauris Norstad gerek Amerikan Dışişleri Bakanlığındaki yetkililer IRBM'leri öncelikle Sovyetlerle sınırdaş olan Türkiye'ye yerleştirmenin Moskova'da şiddetli bir tepkiye yol açabileceğini, bunun da, Avrupa'daki huzursuzluk ve tansiyonu artıracağını öngördüler. Bunun yanısıra Türkiye'ye füze konuşlandırmada öncelik verildiği takdirde ittifak içcrisinde Türklerin bu füzelerle tehlikeli bir şekilde cüretkar ve dövüşken olabilecẹ̆gine inanan Norveç gibi bazı ülkelerde vardı ki, bunlar da Tükiye'yi yanlış bir seçim olarak görüyorlardı. ${ }^{8}$ Norveçlilerin bu düşüncesi çok kısa bir süre önce, 1957 sonbaharında büyük ölçüde Türkiye'nin Suriye'nin Sovyetlere yakınlaşmasına verdiği aşııı tepkiden doğan ve iki bloku karşı karşıya getiren Suriye krizinde Türkiye'nin tutumundan kaynaklanmış olabilirdi. Bu koşullar altında Türkiye istekliliğine rağmen orta menzilli Jüpiterlerin konuşlandırılmasında ilk oncelikli ülke olamayacaktı. Jüpiterlere iliş̧in ilk görüşmeler Fransızlarla başladı. 1958'in hemen hemen ilk yarısı Fransızlarla yapılan sonuçsuz görüşmclerle harcandı ve nihayet De Gaulle yönetimindeki Fransa ile Fransız topraklarındaki tüm nükleer silahların ulusal kontrolünü savunan bir yönetimle anlaşılamayacağı kavrandı ve Fransa'nın Jüpiterlere ev sahipliği olasılığı oradan kalku. Fransa'dan sonra ttalya ile başlayan görüşmeler de gerek iç muhalefet gerekse sürekli değişen koalisyonlar nedeniyle gecikmeler yaşansa da tralya ile Jüpiterlerin konuşlandırılmasına ilişkin andlaşma nihayet Mart 1959'da tamamlandı.

\footnotetext{
${ }^{4}$ Philip Nash, The Other Missiles of October, Eisenhower, Kennedy, and the Jupiters 1957-1963 (Chapel Hill: The University of North Carolina Press, 1997), s.33.

5 Ibid., ss. 7-33.

${ }^{6}$ Ibid., ss. $36-37$; ss. $23-24$.

7 Ibid.,s. 36.

8 Ibid.,s.45.
} 
Türkiye ile gorrüşmelere gelince, 2 Ocak 1959'da, Nato Müttefik Kuvvetler Başkomutanı Norstad, Türkiye ile IRBM'ler konusunda diyaloğa girmek istediğini bildiriyordu. Ayn istek Yunanistan ve Türkiye arasındaki kemikleşmiş zıtlaşma özellikle Kıbns konusunda gözönüne alınarak aynı tarihte Yunanistan'a da götürüldü. Ancak Atina'nın yanıı bir dizi görüşmeden sonra gerek iç muhalefet gerekse Kıbrıs konusunda ¿dün koparma isteği sonucunda olumsuz olacaktı. Türkiye ile olan görüşmelerde ise diğer aday ülkelerden farklı olarak Türkiye'den değil fakat Amerikan bürokrasisinden ve teknik sorunlardan kaynaklanan gecikmeler yaşandı. 9

Konuşlandırma ile ilgili andlaşmalar Aralık 1957 NATO toplantısından hemen hemen iki yıl sonra ttalya ve Türkiye ile surasıyla nihayet 1959 'da imzalanacaku. Ekim 1959 'da imzalanan Türk-ABD andlaşmasına göre füzelere Türkiye malik olurken, nükleer füze başlıkları ABD'nin olacaku. Füzelerin ateşlenmesi ancak Türk ve Amerikan taraflarının onayıyla Avrupa Yüksck Müttefikleri Komutanının emriyle olacaktı. Füze üssünde hem Türk hem de Amcrikalı askerler görev yapacaktı. Bütün bu süre zarfında Eisenhower yönetiminde konuşlandırmaya ilişkin çekinceler Başkan Eisenhower da dahil üst yönetimdeki pek çok kişi tarafından çeşitli kereler dile getirildi; ancak karar alındıktan sonra geri adım atmanın Sovyetler nezdinde ve dünya kamuoyu önünde zafiyet olarak algılanacağı düşünülerek askeri açıdan birçok çekincelere rağmen siyasi bir karar olarak IRBM'lerin konuşlandırılması politikası uygulandı. ${ }^{10}$

Jüpiterlerin hangi ülkelere yerleştirileceği konusu Başkan Eisenhower döneminde çözüme kavuşurken, bunların operasyonel hale gelmeleri ise ancak Kennedy döneminde gerçekleşecekti. Başkan Kennedy iktidara geldiğinde, 1959 yılında Eisenhower döneminde imzalanan ABD-Türkiye andlaşması uyannca konuşlandırılacak olan 15 Jüpiter füzesinin Türkiye'ye gönderilmemesi yönündeki düşünceler $\mathrm{ABD}$ yönetiminde ağırlık kazandı. Buna bağlı olarak Ulusal Güvenlik Konseyi'nin 29 Mart 1961 tarihli oturumunda Başkan Kennedy Dışişleri Bakanlığından George McGhec'nin eşgüdümünde Dışişleri, Savunma Bakanlıkları ve CIA'den temsilcilerin oluşturduğu komiteden Türkiye'ye Jüpiterlerin konuşlandırılması meselesini inceleyip görüşlerini kendisine rapor etmesini istedi. 11 Komitenin kurulmasını izleyen günlerdeki gelişmeler; komiteyi, Başkan Kennedy'ye Jüpiterlerin konuşlandırılması lehinde tavsiye vermeye itecekti. McGhce'nin 22 Haziran 1961 tarihinde Başkanın Ulusal Güvenlik danışmanına konuyla ilgili sunduğu raporda konuşlandırmaya devamın gerekçeleri şöylece sıralanıyordu;

'3-4 Haziran tarihlerinde Viyana'da gerçekleşen Khruschev-Kennedy zirvesinde taraflar arasında özcllikle Berlin konusunda artan tansiyon, IRBM'leri iptal etmeyi olanaksız hale getirdi. Iptal karan hem SSCB hem de müttefikler nezdinde ABD'nin zafiyeti ve ürkerek geri adım atması şcklinde yorumlanabilir; bu da ABD'nin prestijini sarsabilir. Bu gerekçelerle Nato kuvvetleri Başkomutanı Norstad da iptal kararına karşı kesin bir tavır alıyor. ${ }^{12}$ Komite raporunda Türk tarafının muhalefetini de iptalden vaz.geçilmesinde önemli bir etmen olarak sıralıyordu. ABD Dışişleri Bakanı Dean Rusk, iptal meselesini Nisan 1961'deki Cento toplanusında Dışişleri Bakanı Selim Sarper'e açuğında Türk bakanın reaksiyonu kesinlikle negatif olmuştu. Bu görüşler ışığında

\footnotetext{
${ }^{9}$ Ibid., ss.65-69.

10 Bernstein. The Cuban Missile Crisis: Trading the Jupiters in Turkey?'ss.101-102.

$11_{\text {Ibid., s.101. }}$

12 Ibid.
} 
Kennedy yönetimi, eğer Jüpiter projesi iptal edilirse, kendilerinin Türkiye nezdinde sőzzünden dönmüş müttefik konumuna düşeceklerini ve bunun da sadece Türk-Amerikan ilişkilerini değil, tüm NATO-ABD ilişkilerini etkileyebileceği karanna vardı. ${ }^{13}$ Gơrülüyor ki, Jüpiterleri operasyonel hale getirme çalışmalarına devam karannda Viyana zirvesinde ortaya çıkan uzlaşmaz görünüm temel nedeni oluşturduysa, Türkiye'nin muhalefeti de ikincil bir neden olarak gündeme geldi. ${ }^{14} \mathrm{Bu}$ görüşler doğrultusunda komitenin iptale karşıt önerisini destekleyen Başkan Kennedy, Eisenhower yönctimi gibi stratejik yararlılıkları konusundaki ciddi çekincelere rağmen Jüpiterlerin konuşlandırılmasına siyasi kaygılarla yeşil ışık yakacaktı.

Operasyonel hale gelir gelmezde bu füzeler beklenildiği gibi işlevselliklerinin rtesinde bir Sovyet tepkisiyle karşılaşacakt. Zaten Eisenhower yönetimi 1959 Ekim'inde Jüpiter füzelerini Türkiye'de konuşlandırmak üzere andlaşmaya vardığında bunun Sovyetlerce kışkırtıcı bulunacağını düşünüyordu. ${ }^{15}$ Zira kapasitesi ne olursa olsun Sovyetler Birliği kendisine bu denli yakın konuşlandırılan füzelerden doğal olarak rahatsız olacak belki de mukabil bir düzenlemeye girişecckti. Nitekim bu öngörü Khruschev'in Küba'ya füze yerleştirme kararının Türkiye'deki Jüpiterler'in operasyonel hale gelmesiyle aynı zamanlara rastlamasıyla büyük ölçüde doğrulanmış oluyordu. ${ }^{16}$ Füzelerin Nisan 1962'de operasyonel hale gelmesiyle hemen hemen aynı tarihlerde Kınm'da dinlencede olan Khruschev, Savunma Bakan Rodion Malinovski ile Karadenizin ötesinde Türkiye'de konuşlandırılan füzclerin ülkclerini nasıl 10 dakikada vurabileceği konusunu taruşıyor, kendileri için yaratılan bu tedirgenliğin Küba'ya benzer füzeler yerleştirmck suretiyle $A B D$ için de yaratabileceğini belki de ilk kez. gündeme getiriyordu. ${ }^{17}$ Anılarına bakıldığında ise Khruschev Türkiye'deki Jüpitcrlere karşılık Küba'ya füze konuşlandırma fikrinin kendince ilk kez Mayıs 1962'de Bulgaristan'da kardeşlik çerçevesinde bir ziyarette bulunduğu sırada düşünüldüğünü belirtiyor. ${ }^{18} \mathrm{Her} \mathrm{halukarda} \mathrm{Küba'ya} \mathrm{füze} \mathrm{konuşlandırma}$ fikri, Türkiye'de konuşlandırılan Jüpiterlerin operasyonel olmasını izleyen günlerde gündeme geliyor. Buna bakarak Sovyeulerin Küba'ya füze konuşlandırma kararını sadece Türkiyc'deki Jüpiterlere bağlamak abarulı bir çıkarım olsa da Jüpiterlerin Khruschev'in konuşlanđ̊rma kararını almasında önemli bir faktör olduğu sonucuna rahatlıkla varabiliriz.

13. Document 2: Memorandum for McGeorge Bundy on the deployment of 'Turkish IRBM's', June 22, 1961,Chang and Kornbluh, A National Archives Document Reader, s.15; George McGhee. The US-Turkish-NATO Middle East Connection (London: Macmillan Press, 1990),s.166.

${ }^{14}$ Bernstein, Trading the Jüpiters in Turkey?', ss.101-102; Donald L.Hafner, 'Bureaucratic Politics and "Those Frigging Missiles": JFK, Cuba and US Missiles in Turkey', Orbis, Vol.21,1977, .ss.318-319.

${ }^{15}$ Chang and Kornbluh,; A National Security Archive Document Reader, s. XVII.

${ }^{16}$ Raymond L. Garthoff, The Cuban Missile Crisis: An Overview', James A. Nathan (Ed.), The Cuban Missile Crisis Revisited ( New York: St Martin's Press, 1992), s.41.

17 Chang and Kombluh, A National Security Archive Document Reader,s.351.

18 Allyn, 'Essence of Revision', s.147; Garthoff, 'The Cuban Missile Crisis: An Overvicw', ss.41-43. 
Jüpiterler, Küba krizinin nedenlerinden, en azından krizi ağırlaşıran sebeplerden biri olarak deģerlendirilebilse de, asıl rolleri krizin sonuçlandırılmasında gündeme geldi. Daha Sovyet füze rampalarının Küba'da hava fotograflanyla saptanıp, 16 Ekim 1962'de kriz patlak vermeden hemen önce Türkiye'deki Jüpiter füzelerinin Sovyetlere Küba'yla giderek artan askeri ilişkilerinde ve silah yardımında bir ömek teşkil edeceği buna bağlı olarak da füzelerin Sovyetlerce bir pazarlık konusu yapılabileceği ABD yönetiminde giderek artan olçüde taruşılıyordu. ${ }^{19}$ Bobylesi bir pazarlık olasılı̆̆ından tedirgin olan Başkan Kennedy bunalımın hemen oncesinde, 23 Ağustos 1962'de Savunma Bakanlığından Türkiye'deki Jüpiterlerin kaldırılması konusunda neler yapılabileceğini araştırmasını talep etti. ${ }^{20}$ Daha bu araştırmaya bağlı olarak Jüpiterler konusunda bir karara varılmamışı ki, Küba'da SSCB füzelerinin varlığı tesbit edildi ve bir dünya krizi patlak verdi.

Krizin hemen başından itibaren ABD yönetimi hem SSCB'nin bu füzeleri Avrupa'ya yerleştirilen füzelerle pazarlık etmesinden çekinecek, hem de bizzat kendisi son yıllarda açığa çıkan bilgilerden anlaşılıyor ki daha krizin ilk günlerinden itibaren bir füze pazarlığıyla bunalımın çatışmaya dönüşmeden çözülebilme ihtimali üzerinde duracaktı. Henüz daha Khruschev, 27 Ekim 1962'deki mesajıyla dünya kamuoyu önünde Türkiye'deki Jüpiterleri Küba'daki füzelerinin kaldırılmasına karşılık pazarlık konusu yapmadan, ABD kapalı kapılar ardında böyle bir pazarlığın olası olduğunu düşünliyordu. Krizi yürütmekle sorumlu Ulusal Güvenlik Konseyinden seçilen komitede bulunan (Executive Committe of the NSCl) ABD BM Büyükelçisi Adlai Stevenson, Savunma Bakanı Robert Mcnamara gibi isimler krizin başından itibaren olası bir pazarlığı gündemde tutuyorlar; Başkan Kennedy'den de olumlu tepkiler alıyorlardı. ${ }^{21}$ Bu dogrultuda krizin çözümü için Jüpiterlerin pazarlık konusu yapılabilirliğinin sinyalleri Sovyetlere verilecek ve bu konuda bir bakıma Moskova yönlendirilecekti. Krizin çözülmesine ilişkin Kennedy'ye yazdığı 26 Ekim tarihli ilk mektubunda, Khruschev, ABD'nin Küba'yı işgal etmemesine karşılık kendisinin Küba'ya silah sevkiyatını durduracağını belirtmekle yetiniyor, bunu izleyen 27 Ekim tarihli mektubunda ise Küba'daki Sovyet füzelerinin çekilmesine karşılık Türkiye'deki Jüpiterlerin kaldırılmasını talep ediyordu. Bu noktada Jüpiterlerin bunalımın çözümünde nasıl ortaya çıkuğı sorusu gündeme geliyor. Konuyu gündeme getiren 27 Ekim tarihli mesajıyla Khruschev gibi görünse de, son yıllarda ABD'nin bu Jüpiter pazarlı̆̆ını istediği hatta kendisini krizi çözmede ilk kez gündeme getiren taraf olduğu tartışılıyor. Dönemin Washington'daki Sovyet büyükelçisi, Anatoly Dobrynin'e göre Khruschev'in 27 Ekim 1962 tarihli mesajının hemen öncesinde, yani kendilerince Jüpiterler pazarlık konusu yapılmadan birgün önce, 26 Ekim'de Sovyet Elçiliğinde kendisi ve Robert Kennedy arasında yapılan özel bir görüşmede R. Kennedy Türkiye'deki füzeleri krizin çözümlenmesinde kullanmayı önerdi. ${ }^{22}$ Bu görüşme sırasında

19 James G. Blight, Joseph S. Nye, Jr. And David A. Welch, The Cuban Missile Crisis Revisited', Foreign Affair:s, Fall 1987, s.173; Hafner, 'Bureaucratic Politics and 'Those Frigging Missiles', s.313.

- ${ }^{20}$ Chang and Kombluh, A National Security Archive Documents Reader,s.82.

${ }^{21}$ Bemstein, Trading the Jupiters in Turkey?', s.104; s.106.

2227 Ekim öncesi Dobrynin R.Kennedy görüşmesinin tarihi 24 ya da 26 Ekim olması hakkında farklı veriler var. Bakınız; Richard Ned Lebow, "The Trtaditional and Revisionist Interpretations' in James A. Nathan, The Cuban Missile Crisis Revisited (New York:St. Martin's Press, 1992), s.168.; Bernstein, 'The Cuban Missile Crisis: An Overview', s.52; Michael Hunt, Crises in US Forelgn Pollcy, (New Haven: Yale University Press, 1996), s.240; s.246. 
kardeşi Başkan Kennedy'yi arayarak krizin sonuçlandınılması için ülkesinin Türkiye'deki füzeleri kriz sonrasında çekmeye hazır olduğu mesajını Elçinin yanında Başkana doğrulattı. Dobrynin'in bu açıklamalanna dayanarak Sovyetlerin 27 Ekim tarihli mesajlannda Jüpiterlerin çekilmesini talep etmelerinin Dobrynin'in Robert Kennedy'den aldığı mesajı Moskova'ya iletmesinden kaynaklandığı sonucuna varılabilir. ${ }^{23}$ Fakat bu konuda eldeki verilerle kesin bir yargıya varmak güç gözüküyor.

27 Ekim tarihli Jüpiterlerin pazarlık konusu yapılmasına dair Khruschev'in mesajı Washington'a ulaşuğında artık pazarlık dünya kamuoyuna malolmuştu ki, bu da, müttefikler nezdindeki durumu düşünüldügüunde Amerikan yőnetiminin isteyeceği belki de en son şeydi. 27 Ekim'de Kennedy'ye gönderdiği mektubunda Khruschev, ABD'nin Türkiye'deki Jüpiter füzclerini sőktüğgü takdirde kendisinin de Küba'daki benzer füzeleri sőkeceğini ve Sovyetler Birlið̌inin Türkiye'nin toprak bütünlüğüne ve hükümranlığına saygı göstereceğini, içişlerine karışmayacağını ve işgal etmeyeceğini belirtmiş ve Küba'daki füzelerin sökülmesi için ABD'nin de aynı güvenceleri vermesi gerekeceğini eklemiştir. ${ }^{24} \mathrm{ABD}$ yönetimi bu pazarlığı dünya kamuoyu önünde kesin bir dille reddetti. Oysa kamuoyuna yansıyan bu tavnnın aksine 27 Ekim tarihli mesajın Washington'a ulaşuğı günün akşamında, gizli Robert Kennedy-Dobrynin görüşmesinde, ABD daha önce yeşil ışık yakuğı bu pazarlığı kapalı kapılar ardinda onaylayacak, füzelerin krizden sonra birkaç ay gibi kısa bir süre içinde kaldırılacağı güvencesini yazılı bir andlaşma olmaksızın Sovyetlere verecekti. 25 Son yıllarda açığa çıkan belgelerden anlaşılıyor ki, ABD, eğer SSCB bu gizli andlaşmaya yanaşmasayd̆ da; aynı öneriyi bir BM önerisi gibi dünya kamuoyu önünde tekrar ettirecekti, ve bunun için hazırlıklar tamamlanmışu. ${ }^{26}$ Zira Jüpiterleri pazarlık etmek gibi nispeten kabul edilebilir bir zararla çatışmadan kurtulmak konusunda Kennedy yönetimi çok kararhydı.

27 Ekim akşamı yapılan bu tarihi gizli görüş̧ıeden çok az kişi haberdar oldu ve uzun yıllar bu görüş̧menin varlığı bilinmedi. Bu nedenle de Küba bunalımı uzun süre Kennedy'nin kriz yönetimindeki üstün başarısı şeklinde lanse edildi. 26 Ekim tarihli R.Kennedy-Dobrynin görüşmesini yok saysak dahi, Sovyet yönetimi pazarlık önerdikleri 27 Ekim tarihli mesajlarının öncesinde ABD'nin Jüpiterleri pazarlık konusu yapabileceğini gayet iyi biliyordu; zira $A B D$ 'nin bu füzeleri kaldırmaya birkaç kez teşebbüs ettiğinden haberdardı. ${ }^{27}$ Bunun yanısıra ABD'nin önde gelen gazetelerinde Küba'daki Sovyet füzeleriyle Türkiye'deki Jüpiterler arasında paralellik kuran çeşitli yazılar da Sovyetleri böylesi bir pazarlık talebi konușunda yönlendirmiş olabilirdi. Füze pazarlığına yol açan neden ne olursa olsun pazarlık gündeme geldiğinde özellikle ABD

${ }^{23}$ Chan and Kombluh, A National Security Archive Documents Reader, s.83.

24 Foreign Relations of the United States (FRUS) 1961-63, Cuban Missile Crisi and Aftermath, 1962-63 - Meeting and Memoranda Series, Vol.XI, 27 October 1962, 17 of 24; 18 of 24, US Dep. of State Web Site, Electronic Research Collection, UIC Library.

$25_{\text {Ibid., } 22 \text { of } 24 .}$

27 Ekim tarihli Robert Kennedy- Anatolia Dobryrin görüşmesinden ilk kez Robert Kennedy'nin ' 13 Days the Cuban Missile Crisis' adlı anılarında bahsedildi. Ancak 26 ekim tarihli görüşmeden bu anılarda hiç söz edilmiyordu.

26FRUS, 1962-63 volXI, 27 October 1962, 24 of 24.

27 Bern Greiner, The Cuban Missile Crisis Reconsidered - The Soviet View: An Interview with Sergo Mikoyan', Diplomatic History, 1990, Vol.14,s.216. 
açısından onemli riskler taşıyordu. Bu pazarlığın dünya kamuoyunca bilinmesi ozellikle müttefiklerince duyulması ABD'ye önemli ölçüde prestij kaybettirebilir, ABD'nin Sovyetler karşısında zafiyet göstermesi şeklinde yorumlanabilirdi. Bu nedenle de bu pazarlıktan, Kennedy yönetiminde, krizi yöncten gruptan bile sadece çok az sayıda kişi haberdar oldu. 28 Gerek ABD gerekse Sovyetler Birliği krizin çözümünde yüzlerine tutanak etmek üzcre Jüpiterleri kullanmakta büyük fayda gördüler. Khruschev, ABD'ce zaten kaldırılması düşünülen, stratejik olarak pek çok zaafı bulunan Jüpiterlerin kaldurilmasını talep ederek, Kennedy de ote yandan zaten polaris füzeli denizaltular devreye girdiğinde kaldırmayı düşündüğü füzeleri Sovyet talebi karşısında sökmeyi dünya kamuoyu ơnünde reddederek, krizi çözme aşamasında ödün vermeyen, güçlü lider imajını pekiştirme olanağı buldular. Böylece özcllikle $A B D$, kriz öncesinde çeşitli kereler konuşlandurmaktan vazgeçtiği Jüpiterler yüzünden kenđini dünya kamuoyu önünde bir pazarlık içinde buluyor fakat aynı zamanda yine bu aynı füzeler kendisine krizden savaşa gitmeksizin sıyrılmak için bir kapı aralıyordu.

\section{Türkiye açısından Jüpiter Füzelerinin Değerlendirilmesi}

Jüpiterler süpergüçler açısından krizden çauşma olmaksızın sıyrılmak için bir şans haline dönüşürken, Türkiye için durum biraz farklıydı. Krizin tümü hakkında son yıllarda yapılan yeni değerlendirmeler, Jüpiterler dolayısıyla bunalıma taraf olan Türkiye için de yeni çıkarımlar içeriyor. Her ne kadar Türkçe birincil kaynak eksikliği Türkiye'nin krizdeki pozisyonunu tam olarak değerlendirmede ónemli açmazlar getirse de, son ylllarda krizin dị̆er taraflarnnca ifşa edilen belgeler ve görüşler Türkiye perspektifine de, bir olçüde de olsa, yeni bir boyut katyor.

Jüpiterler krizin çözümü aşamasında gerek ABD gerek SSCB için cankurtaran simidi haline dönüşürken, Türkiye için kendisinin öngörmediği farklı durumlar yaratıyordu. 1957 yılında Eisenhower yönetiminin Avrupa'da orta menzilli füzeler yerleştirme karanna Ingiltere ve ltalya ile birlikte onay veren üçüncü ülke olan Türkiye bu füzeler dolayısıyla genel olarak NATO iltifakı içinde önemini öne çıkarmayı, ABDTürkiye ilşkilerinin yakınlığını sergilemeyi düşünürken hepsinden önemlisi bu füzelerin kendi güvenliğini artıracağına samimi bir biçimde inanıyordu. ${ }^{29}$ Gerck Başbakan Adnan Menderes gerek Dışişleri Bakanı Fatin Rüştü Zorlu Jüpiterlerin birtakım zafiyetlerinin farkındaydılar ancak kendi savunmaları ve de NATO savunması için nükleer silahlar da dahil, olabildiğince silahlanmaktan başka çare görmüyorlardı ve bu nedenle de orta menzilli füzelerin Avrupa'ya yerleştirilmesi gündeme gelir gelmez bu ABD önerisini coşkuyla karşıladılar. ${ }^{30}$ Silahlanmayı arurmayı Sovyetlere karşı en iyi savunma aracı, en azından araçlarından biri olarak gördükleri ve buna bağlı olarak da nükleer silahlardan arınmıs bölge kurulması gibi Sovyet tekliflerini kesinlikle reddetikleri düşünülürse Menderes hükümetinin Jüpiterlere gösterdiği olumlu tepki şaşırtıcı değildi. Jüpiterleri topraklarina kabul etmeye karar verdikten sonra, Türkiye füzeler konusundaki olumlu

\footnotetext{
${ }^{28}$ Chang and Combluh, A National Security Archive Documents Reader, s.377.

${ }^{29}$ Mehmet Gönlübol, 'NATO and Turkey An Overall Appraisal,' Turkish Yearbook of International Affairs, XI, 1971.; Bernstein, 'The Cuban Missile Crisis: Trading the Jupiters in Turkey?', s.100.

${ }^{30} \mathrm{Nash}$, The Other Missiles of October, s.65.
} 
tavnn konuşlandırmaya ilişkin görüşmelerde de fazlasıyla gösterdi. ${ }^{31}$ Ömeğin, ttalyanlar görüşmelere devam etmek için $\mathrm{ABD}$ baskısı görürken, Türkler ABD'yi görüşmelerde yeterince hızlı olmamakla suçlayacaku. ttalya'dan farklı olarak o dönemde Türkiye'yi bu goruişmelerde çekinceli taraf yapacak ciddi bir iç muhalefet ya da istikrarsız bir koalisyon hükümeti yoktu. Menderes hükümeti'nin Jüpiterler konusundaki bu iyimser tavn 1960 darbesiyle iktidara gelen askeri yönetim ve onu izleyen Ismet Inönü liderlið̌indeki koalisyonlarda da (1961-63) sürdürüldü. Yine bu görüşe paralel olarak Türkiye 1961 yllında ve 1962 yazında birkaç kez ABD'nin füzeleri çekme talebini reddetti. flk talep 27-28 Nisan 1961 Nisan tarihlerinde Ankara'da CENTO toplantısında Dışişleri Bakanı Rusk tarafindan askeri darbeden sonra kurulan Cemal Gürsel Kabine'sinin Dışişleri Bakanı Selim Sarper'e iletildi. Sarper bu öneriyi füzeler için ödeneğin daha yeni mecliste onaylandığını, bu nedenlede şu anda füzelerin çekilecę̧ini meclise bildirmenin hükümeti için utandınıcı olacağını söyleyerek öneriyi reddetti. ${ }^{32}$ Sarper'in ileri sürdüğ̈ü mazeret verilen red kararında nedenlerden sadece biri olabilirdi. Herşeyden önce yeni askeri yönetim için bu füzelerin çekilmesini kabullenmck ciddi riskler getirebilirdi. Füzelerin ABD-Türkiye ittifakı düşünüldüğünde simgesel bir yanı vardı. Bu füzelerin çckilmesi ABD'nin Türkiye'ye sırt çevirdiği ya da Türkiye'nin bir müttefik olarak önemini yitirdiği şeklinde yorumlanabilirdi ki, bu da, ülkede gücünü pekiştirmek isteyen askeri yönetim için pek istenecek birşey değildi. ${ }^{33}$ Dışişleri Bakanı Rusk Jüpiterler yerine Akdenizde konuşlandırılacak Polaris füzelerini taşıyacak atom denizaltularını Bakan Sarper'e önerdiyse de bunların Türkiye topraklarına konuşlandırılan Jüpiterler kadar ABD'nin Türkiye'ye yönelik savunma garantisini ve işbirliğini simgelemeyeceği düşünüldü; aynca da Polarisler henüz hazır da değildi. ${ }^{34}$ Jüpiterlerin geri çekilmesine ilişkin Nisan 1961 ABD ơnerisi bir başka açıdan da talihsiz. bir zaman dilimine rastlıyordu; zira tam bu dönemde ABD "kitlevi mukabele doktrini" yerine "esnek mukabele doktrini"ni yeni NATO stratejisi olarak gündeme getiriyordu ki; Türk yetkililer de bu doktrin çerçevesinde Jüpiterlerin geri çekilmesi teklifini Amerika'nın nükleer sorumluluklarından kaçışı şcklinde yorumlamış ve dolayısıyla da teklifi reddetmiş olabilirlerdi. ${ }^{35}$ Bütün bunlara bağıı olarak 1962 yılı Mayıs ayında Amerikan Dışişleri Bakanı Rusk Oslo'daki Nato Bakanlar toplantısında ve yine aynı yılın Haziran ayında ABD Dışişlerinden George Ball Washington'daki Türk Büyükelçisine Başkan'ın dircktifiyle iki kez daha Jüpiterlerin geri çekilmesini önerdiklerinde, Ankara'dan yanıt yine olumsuzdu ve sözü edilen bu koşullar alında da pek şaşırtıcı değildi. ${ }^{36}$ Ancak belki Türkiye bu füzeler yüzünden müttefikleriyle birlikte bir nüklecr savaşın eşiğine gelmeyi tahmin etmek gibi oldukça zor bir öngörüde bulunabilseydi, durum bclki biraz. farklı olabilirdi.

Türkiye, yukarda belirtilen nedenler doğrultusunda konuşlandırmanın iptaline kendince belki haklı bir dizi neden!e muhalefet ederken, öte yandan güvenliği açısından yeni riskler almış oluyordu. Daha 1959 yılında Menderes yönetimi füzelere ilişkin ABDTürk andlaşmasını imzalar imzalamaz Sovyet protestosuna maruz kalacaktı ki bu beklenen bir tepkiydi. Ancak Moskova bu tedirginliği ifade etmekle de kalmayıp, bu

${ }^{31}$ Feroz Ahmad, The Turkish Experiment in Democracy 1950-1975 (London: C.Hurst\&Company, 1977), s.397.

32 Chang and Kombluh, A National Security Archive Documents Reader, s.349.

33 Bernstein, Trading the Jupiters in Turkey', ss. 107-108

${ }^{34} \mathrm{Nash}$. The Other Missiles of October, s.98.

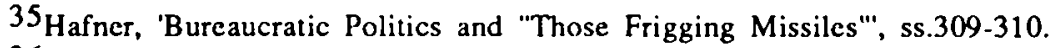

36 Ibid., s. 321 . 
oluşuma Küba'ya füze konuşlandırmak suretiyle 1962 yllında sözlü protestolar yerine pratikte bir cevap vermeye kalkışınca Türkiye'deki füzeler Küba'ya yerleştirilen SSCB füzeleri için bir bakıma ilham kaynağı oluyor ve böylece bir dünya krizinin çıkmasında dolaylı da olsa bir faktör oluyordu. Böylece kriz çıktı̆̈ında Türkiye öngörmediği bir şekilde kendisinden millerce ötede patlak veren bir bunalıma taraf oluyor, bu kadar uzaklıktaki bir çatışmanın kendisini nasıl yakından etkileyebileceğinin ilk şokunu yaşıyordu. ${ }^{37}$ Taraf olmakla da kalmayıp tistelik hedef haline geliyordu. Kriz patlak verdiğinde krize ilişkin askeri çözümler üretildiğinde gerek SSCB gerek ABD Türkiye'yi Jüpiterler itibariyle ilk hedeflerden biri olarak belirliyorlardı. ${ }^{38}$ Son yıllarda yaplan değerlendirmelerden anlaşılıyor $\mathbf{k i}$, kriz bağlamında Türkiye oncelikli hedeflerden biri olmakla kalmıyor, bir ilk saldın durumuyla karşılaş̧ư̆ında arkasında otomatik bir ABD desteği bulamayacağı da yine bu krizde çarpıcı bir şekilde ortaya çıkıyordu. Yani NATO müttefiki olmanın Türkiye'nin güvenliğini garantilemediği açıkça ortaya çıkıyordu. 27 Ekim tarihli krizden sorumlu Yürütme Kurulu toplanusının tutanaklarından anlaşlliyorki eğer Sovyetler ilk hedef olarak Jüpiterleri vurursalar ABD'nin buna otomatik bir şekilde tepki vermesi sőzkonusu değildi. Belki de çatışmanın bu saldırıyla sınırı kalması için tepki göstermeyebilecekti. ${ }^{39} \mathrm{Bu}$ durumda anlaşıllıyor $\mathrm{ki}$, Türkiye bu füzelerle güvenliğini arturmak bir yana büyük güvenlik riskleri de almış oluyordu. Diğer yandan Türkiye bu füzeleri ülkesine kabul ederken bunu güçlü Türk-ABD ilişkilerinin bir sembolü olarak düşünüyordu, oysaki, aynı füzeler yüzünden gizli bir ABD-SSCB pazarlığı gündeme gelecek, bu da, Türk-ABD ittifakının zafiyctini özellikle de bu ilişkide Türkiye'nin edilgenliğini vurgulayacaktı.

Kriz patlak verdiğinde iktidarda bulunan Inönü liderliğindeki CHP-YTP-CKMPBağımsızlar koalisyon hükümeti hiç tereddütsüz müttefiki ABD'yi destekledi. ${ }^{40}$ Meclisteki bütün partiler bu destek konusunda hemfikirdi. ${ }^{41} 22$ Ekimde ABD Sovyetlerin Küba'daki füze yığınağına ilk tepki olarak abluka karanıı açıklar açıklamaz, Türkiye bunu ilk destekleyen ülkelerden biri oldu. ${ }^{42} \mathrm{Bu}$ arada krizin başından itibaren hükümet kendi toprakları üzerindeki füzelerle Küba'daki füzeler arasında bağlantı kurulmasından fazlasıyla rahatsız olmuştu. Bu ncdenle de Dışişleri Bakanı, Batı basınında gündemde tutulan Küba-Türkiye paralleliği yüzünden tedirgin olduklannı ABD'ye bildiriyor ve askeri yardımın artırılmasını ve hemen acilen bazı uçakların ve uçak parçalarının Türkiye'ye gönderilmesini talep ediyordu. Washington, Küba-Türkiye konusundaki karşılaşırmalar konusunda Ankara'nın müsterih olmasını ögüulleyerck, Türkiye'nin askeri yardımların hızlandırılması talebini olumlu karşılıyordu..$^{43}$ Aynca da,

37 Yön, 31 Ekim 1962.

${ }^{38}$ Greiner, "The Soviet View: An Interview with Sergo Mikoyan', s.216.;

${ }^{39}$ Doc.49: Transcript of the Executive Committee meeting. October 27, 1962, Chang and Kornbluh, A National Security Archive Documents Reader, s.214; A Marc Trachtenberg. 'Commentary: New Light on the Cuban Missile Crisis?', Diplomatic History: Vol.14, 1990, s.243.

40 Ismet Inönü'nün TBMM'deki Konuşmaları 1920-73 (Ankara: TBMM Kültür Yayınlar 1992), s.75; Metin Toker, Demokrasimizin Ismet Paşalı Yılları Inönü'nün Son Başbakanlığı (Ankara: Bilgi Yayınevi, 1992), s.140.

41 Yön, 31 Ekim 1962.

42 Mehmet Gönlubol ve diğerleri, Olaylarla Türk Dış Polltikası (1919-1990)

(Ankara: Siyasal Kitabevi, 1993), s.328.

${ }^{43} \mathrm{Nash}$, The Other Missiles of October, ss.137-138. 
bu sıralarda kapalı kapılar ardında SSCB-ABD gizli pazarlığı için çalışmalar sürerken, $A B D$ ve Türk hükümellerinin Küba ve Türkiye'deki füzeler arasında benzerlik kuran ve bir pazarlık ongören çeşitli yorumlan ayn gerekçelerle birlikte reddettikleri Türk basınından izlencbiliyordu. Füzeler arasındaki benzerliği ve dolayısıyla olası bir pazarlŭ̌ı reddederken, ABD ve Türk yönetiminin şu tezleri ileri sürdükleri görülüyor; Küba'daki ussler Sovyet Rusya ile Küba arasında yapılan ikili andlaşmalara dayanmaktadır. Oysa Türkiye'deki üsler ise ABD'nin değil NATO'nundur. ${ }^{44}$ Ayrıca Türkiye kendisinin ABD ile ilişkisinin Küba-Sovyet ilişkisine benzetilmesinden de rahatsızd, çünkü kendisi Küba'yı Sovyetlerin kuklası olarak gorüyordu. ${ }^{45}$ Ayrıca Türkiye'deki üsler savunma amaçlıdır, çünkü 1957'de Sovyetlerin nükleer silahlar konusundaki ataklarına karşılık savunma amaçlı olarak konuşlandırılmışur deniyordu. Ve bu konuşlandırmanın SSCB'nin Küba'ya yapuğı gibi el altundan değil dünya kamuoyu önünde açıkşa gerçckleştirildiği vurgulanıyordu. ${ }^{46}$ Böylece böylesi bir pazarlığın olanaksızlığı ileri sürülürken Türkiye'deki füzelerin ancak genel bir silahsızlanma çerçevesinde ele alınabileceği vurgulanıyordu. 47 Oysaki bu açıklamalar görünüşü kurtarmaktan başka bir anlam taşımıyordu; zira ABD krizin başından itibaren bizzat kendisi Küba ve Türkiye'deki füzeler arasında parallelik kurmuş nihayctinde de füze pazarlı̆̆ına girişmişti.

Krize diplomatik bir çözüm bulabilmek için Jüpiterlerin pazarlık edilmesi gündeme geldiğinde, Türkiye'nin böylesi bir pazarlıktan haberdar edilmemesi kararlaşurıldı. Kriz öncesi Türkiye en az üç kez ABD'nin Jüpiterleri kaldırma girişimine negatif yanıt verdiğinden, bu kez de benzeri nedenlerle olumsuz yanıt vereceği düşünülerek Türk hükümetine pazarlık konusunda direkt görüş sorulmadan Ankara'daki ABD Büyükelçisi Raymond Hare ve NATO nezdindeki Büyükelçi Thomas Finletter'dan 24 Ekim 1962'de füzelerin kaldırılmasına ilişkin muhtemel Türk reaksiyonu hakkında görü̧̧̧ bildirmeleri istendi. ${ }^{48}$ Büyükelç̧ Hare raporunda bir pazarlık sonucu Jüpiterlerin kaldırılmasının Türk-ABD ilişkilerine zarar vereceğini çünkü hem askeri hem de politik açıdan Türk hükümetinin bu füzclere büyük öncm atfettiğini bildirdi. Hare gibi Finletter de böylesi bir pazarlığa tcpkinin olumsuz olacağını ve eğer böylesi bir pazarlık duyulursa diğer NATO ülkelerinin de acaba bizden de Jüpiterler benzeri askeri ödünler mi istenecek sorusunu soracakların, bununda ittifak içinde güvensizlik yaratacağını bildirdi. ${ }^{49}$ Belgelerden anlaşllyyor ki tepkisi nötr ya da olumlu olsa bile ABD yönetiminin bunu Türk hükümeti ile müzakere etmesi oldukça zordu; zira bu pazarlıktan ABD yönetiminde bile sadece 3-5 kişi haberdar oldu. Buna örnek olarak 27 Ekim'deki gizli anlaşmaya rağmen ABD Dışişleri Bakanlığı Büyükelçileri Finletter ve Hare'e 29 Ekim 1962'de Jüpiterlere ilişkin herhangi bir pazarlı̆ga girişilmediği konusunda güvence verecekti. ${ }^{50}$ Türkiye gizli bir pazarlıktan habersiz ABD'nin dünya kamuoyu ơnünde her türlü pazarlığı reddetmesinden fazlasıyla hoşnut kaldı. Bu hoşnutluğunu da hükümet Washington'daki

44 Millyet, 28.Ekim.1962; Cumhuriyet, 28.Ekim.1962.

45 Doc. 50: Cable Received from US Ambassador to Turkey Raymond Hare to State Department, regarding Turkish Missiles, October 27, 1962 in Chang and Kombluh, A

National Security Archive Documents Reader, s.221.

${ }^{46}$ Cumhuriyet, 26.Ekim.1962; Milliyet, 28.Ekim.1962.

47 Milliyet, 28.Ekim.1962.

${ }^{48}$ Chang and Kombluh, A National Security Archive Documents Reader, s.370.

${ }^{49}$ FRUS 1961-1963, Vol.XI, 24 Ekim 1962, 4 of 18.

${ }^{50}$ Bernstein, 'Trading the JupitersI?',s.124. 
Büyükelçisi aracilığıyla 29 Ekim 1962'de Amerikan Dışişleri Bakanlığına bildirecekti. ${ }^{51}$ ABD'nin bu görünen politikasıyla gerçek politikası arasındaki fark düşünülürrse Türkiye gözardı edilen, yanhş yönlendirilen bir müttefik konumuna düşüyordu.

Ancak bu demck değildi ki Inönü yönetimi bunalımın hị̧ bir aşamasında ya da daha sonrasında arkalarından bir iş çevrilmediği kuşkusuna kapılmadı. Aslında büttün bu gizliliğe rağmen, gerek kriz sırasında gerekse kriz sonrasında böylesi bir pazarlı̌̆ın olabilirliğinin ipuçlarını sürmek Türkiye açısından pek de zor değildi. Bir kere krizin başından itibaren gerek Bat gerek Sovyet basınında Küba-Türkiye paralelliği ve bu ülkelerdeki füzelerden karşılıklı vazgeçilmesinin krizden çıkmak için en iyi yol olduğu yoğun bir şekilde dile getirildi. Bunun yanısıra bizzat Ankara'daki Sovyet Büyükelçisi Nikita Ryzhov 23 Ekim 1962'de Türkiye'nin ABD'nin Küba'sı olduğunu söylüyor, daha sonra da Dışişleri Bakanı Feridun Cemal Erkin'den Jüpiterlerin sökülmesini talep ediyordu. Bu Moskova'nın iki ülkedeki füzclcr arasında parallellik kurduğunun net ve açık bir ifadesiydi ve krizin çözümünde Jüpiterlerin önemini vurguladığından da Türkiye'yi fazlasıyla tedirgin etti. ${ }^{52}$ Nitekim 27 Ekim tarihli Khruschev'in mesajıyla Jüpiterlerin krizden sıyrılmaktaki ơnemi hiç bir şüpheye yer bırakmaksızın ortaya çıkı̆ğında; Türkiye'nin bu noktada birtakım gizli anlaşmalara vanlabilcceği konusundaki kuşkuları arttı. Bundan başka daha önce çeşitli defalar Jüpiterlerin geri çekilmesi önerisi bizzat Amerikalılarca kendilerine yapıldığından, Türkıcr, ABD için füzelerin sökülmesini içeren bir pazarlığının kabul edilebilir olduğunun da çok iyi farkındaydılar. Hepsinden önemlisi Khruschev'in, 27 Ekim tarihli Jüpiterlerin sökülmesini isteyen mesajından sonra, hemen bir u-dönüşü yaparak, 28 Ekim'de bu isteği yerine getirilmeden Küba'dan Sovyet füzelerini çekeceğini ilan etmesi Ankara'nın muhtemel bir pazarlık konusundaki kuşkularını daha da artırdı. Bu nedenle de 28 Ekim'de, Dışişleri Bakanı Erkin, ABD Büyükelçisi Hare'e Jüpiterleri kastederek Türkiye'ye danışılmadan kendilerini ilgilendiren bir şeyin yapılmayacağını farzettiğini söyledi ve bu konuda Büyükelçinin onayını aldı. 53 Aynı zamanda ABD'nin BM nezdindeki Büyükelçisi de Türkiye ve Nato'ya danışılmadan Jüpiterlerle ilgili bir müzakereye Washington'un girişmeyeceği güvencesini Türkiye'ye veriyordu. ${ }^{54} 28$ Ekim'de Khruschev'in ani bir çıkışla Küba'daki füzcleri çekeceğini açıklayıp krize son vermesi kadar, belki de daha fazla Türkiye'yi gizli bir pazarlık konusunda kuşkulandıran krizden hemen sonra $\mathrm{ABD}$ 'nin Jüpiterleri sökme girişiminde bulunması oldu. 55 Bütün bu sözzü edilen gelişmeler karşısınnda muhtemelen Türkiye bir pazarlık olasılı̆̆ı hissetti, fakat bunu ifşa etmek ya da gündeme getirmek bir müttefik olarak ve de $A B D$ 'yle ilişkilerine özel önem atfeden koalisyon hükümeti için takınılacak isabetli bir tavır olamazdı. Bu nedenle kamuoyu önünde belki varolan şüphelerini hiç gőstermediler ve ABD'nin pazarlık yapmadığına ilişkin inançlarını defalarca tekrarlamayı yeğlediler.

Buna bağlı olarak da Amerikalılar Jüpiterlerin sökülmesini gündeme getirdiklerinde Türkler konuşlandırmada olduğu gibi belki hevesli değil ama yine uyumlu

\footnotetext{
51 FRUS 1961-63, Vol.XI, 29 Ekim 1962, 8 of 20.

$52 \mathrm{Nash}$, The Other Missiles of October, s.137.

53 Ibid., s. 163 .

54 Ibid.

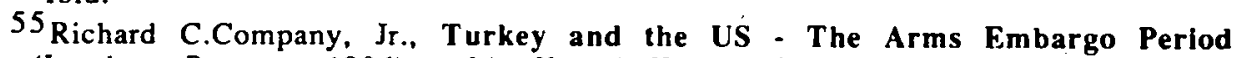
(London: Praeger, 1986), s.24; Kemal Karpat, Turkey's Forelgn Policy in Transition (Leiden: E.S Brill, 1974), s.91.
} 
davrandilar. Aralık 1962 NATO Bakanlar Konferansı'nda Amerikan Savunma Bakanı McNamara ve Dışişleri Bakanı Rusk sırasıyla Savunma Bakanı llhami Sancar ve Dışişleri Bakanı Erkin'e sökülme meselesini açıklarında Sancar sökülmeye ilişkin olarak bunun Türkiye'nin moralini ve NATO'ya güvenini etkileyeceğini söylerken ;Erkin daha yumuşak bir tavırla ABD'nin Türkiye'nin güvenliğine olan hassasiyetini Jüpiterler yerine başka bir biçimde yine etkin olarak gösterdiği sürece füzcleri sökmenin büyük bir sorun olmayacağını belirtti. Bu tepkiler karşısında Kennedy yönetimi Türkiye'nin bazı jestlerle ikna edilebileceğini düşünerek biran önce göndereceği F-104G uçaklarıyla Türk Hava kuvvetlerini güçlendirmeye ve Türkiye'ye artan miktarda konvansiyonel silahlar sağlamaya karar verdi. 56 Washington'un beklediği gibi bu jestler semeresini verecek Türkiye Jüpiterlerin kaldırılmasını kabul edecekti. Jüpiterlerin sökülmesi konusundaki görüşmeler Türk-ABD yetkililer arasında doludizgin giderken Türk siyasi çevrelerinde de Jüpiterlerin sőkülmesinin ABD'nin gündeminde olduğu seziliyor ve bu hareketin arkasında yatan mana irdeleniyordu. Ancak bu konuda Inönü hükümeti, görüşmeler $\mathrm{ABD}$ ile kesin bir sonuca varnncaya kadar, füzelerin konuşlandırmasında Menderes hükümetinin yapı̆̆ı gibi sessiz ve yorumsuz kalmayı yeğledi. Mecliste 1963 Ocak'ının ilk yanısında yapılan ve birkaç gün süren diş politika konusundaki bir genel görüşmede Nihat Erim, Ali Naili Erdem gibi bazı milletvekilleri, hükümetin jüpiterler konusunda gizlilik içinde davrandığını söyleyerek Dışişleri Bakanından Jüpiterlerin akibeti konusunda açıklama yapmasını istediler. Jüpiterler dış basında yazıldı ’̆ı gibi sökülüyor muydu? Sökülüyorsa bu Türkiye'nin stratcjik öneminde bir azalmaya $\mathrm{m}$ işaretti? Bakan Erkin cevabi konuşmasında Jüpiterlerin söküleceğine dair henüz bir karar alınmadığını belirtmekle yetinip, ABD ile süregiden müzakerelere değinmemeyi yeğledi. Ancak konuşmasında Polarisleri kastederek Jüpiterler kaldırılırsa bunların yerine Türkiye'nin güvenliğini daha da iyi sağlayacak bir savunma sisteminin getirileceği konusunda meclisi temin etmekle yetindi. Türkiye'nin stratejik değcri azalıyor mu? sorusuna gelince Bakan bunu kesinlikle reddederek, esnek mukabele doktrinine istinaden 'NATO camiasında en salahiyetli şahsiyetler, yeni strateji icaplarının, nükleer silahlara daha ziyade kalkan, klasik silahlara ise kılıç rolünü vermekte olduğunu düşünmektedirler... Bu itibarla, NATO ittifakı dahilinde, klasik kuvveuler bakımından en önemli iştiraki sağlayan ülke olması sebebiyle, memleketimizin stratcjik değcrinde şayet bir tahavvül vuku bulacak ise, böyle bir tahavvülün Türkiye için ancak ve ancak daha müspet bir şekilde tecelli edebileceğini belirtmek isterim' seklinde cevap verecekti. ${ }^{57}$ Meclisteki bu tartışmalar Milli Savunma Bakanı Sancar'ın 23 Ocak 1962'de NATO ittifak sisteminin daha etkili nükleer silahlarla savunmasını sağlamak için polaris füzelerinin Türkiye'deki Jüpiter füzclerinin yerini alacağını Meclise bildirmesiyle sona erecekti. ${ }^{58}$ Jüpiterlerin sökülmesine 1 Nisan 1963'de başlandı ve tamamlanması sadece birkaç hafta sürdü. Aynı tarihlerde Akdenizde konuşlandınlan Polaris güdümlü füzeleri ile yüklü atom denizalularından biri, USS Sam Houstan, 14 Nisan 1963'te Amerika'nın Jüpiterlerden sonra Türkiye'nin güvenliğine gösterdiği hassasiyetin devamının bir göstergesi olarak tzmir limanını ziyaret etti. Bu ziyaret Ankara'da memnuniyetle karşılandı. 59

56 Nash, The Other Missiles of October, ss.163-164; Oral Sander, TürkAmerikan Ilişkileri, (Ankara: A.I.SBF. Yayını), s.223.

57. Millet Meclisi Tutanak Dergisi, B:30, 14.1.1963.

58 bid., B:34, 23.1.1963.

${ }^{59}$ Feroz ve Bedia Turgay Ahmad, Türklye'de Çok Partili Politikanın Açıklamalı Kronolojisi 1945-71 (Ankara : Bilgi Yayınevi, 1976), s.260. 
Kısa dơnemde gizli SSCB-ABD pazarlığından haberdar olunmadığından Jüpiterlerin sökülmesi Türkiye'de ABD-Türkiye ilişkileri açısından büyük bir infial yaratmadi. Ancak birkaç yll sonra, ozellikle uzun vadede 1964'deki meşhur Johnson mektubundan sonra, ABD-Türkiye müttefik ilişkisinin yoğun bir şekilde sorgulanmaya başlandığı bu dönemde Jüpiterlere ilişkin sökme kararının ABD'ce tek taraflı alınması ve sonradan Türkiye'ye kabul ettirilmesi söz konusu olduğundan Küba krizi Washington'un bir müttefik olarak Türkiye'yi nasıl gözardı edebileceğinin ve Türkiye'nin de nasıl edilgen bir konuma sokulabileceğinin ilk ciddi orneği olarak değerlendirilmeye başland. Böylece Jüpiterlere ilişkin gizli pazarlı̆̆ın varlığı bilinmeden bile uzun dönemde kriz ABD-Türk ilişkileri açısından ittifak ilişkisini pekiştirici değil aksine Türkiye açısından ABD'ye yőnelik kuşkuları artırıcı oldu. Ǒte yandan Küba krizine bağlı olarak Jüpiterlerin kaldırılmasından sonra Türkiye füzelerle SSBC'yi direkt tehdit eden bir konumdan uzaklaşmış olduğundan bu durum iki ülke ilişkilerinin olumlu gelişmesinde pozitif bir etmen oldu. 